第 29 回日本耳科学会総会・学術講演会 初めての耳科学会賞

第 81 回耳鼻咽喉科臨床学会総会・学術講演会 ポスター賞

iPhone を用いた顔面神経麻痺評価アプリの開発

長谷部 孝毅, 堀 龍介, 児嶋 岡, 岡上 雄介, 藤村 真太郎, 鹿子島 大貴, 田口 敦士, 庄司 和彦

天理よろづ相談所病院 耳鼻咽喉科

【目的】顔面神経麻痺疾患において，予後予測，治療効果判定のために正確な評価が必要である．誘発筋電図 (electroneurography; ENoG) などの電気生理学的評価方法の他に，柳原法などに代表される顔面各部位の動きを 評価し，その合計で麻痺程度を評価する主観的評価方法が簡便であり広く使われている．しかしながら，顔面表 情の動きを見た目で評価する方法は複数あるものの，いずれにも共通する欠点として，あくまで主観的評価のた め検者間で差異が生じる可能性がある他，各部位は 3 段階評価のため，わずかな改善などを点数では評価しきれ ないという点が挙げられる．それらを解決する方法として，画像解析による評価方法はいくつか報告されている が，解析の手間や装置の問題などから広くは使われていない. 一方で，近年米 Apple 社の販売するスマートフォ ン (iPhone X 以降) は，その認証方式として顔認証を用いており，顔面運動を正確に捉えることが可能である. そ こで我々は，顔面神経麻痺に対する客観的かつ簡便な評価方法を確立することを試みた。

【方法】iPhone XS を用いて検証した. 各顔面の部位の動きを係数化し最大值を取得し，左右の比較を行うことで 顔面神経麻痺を評価するアプリを作成した．それを用いて外来受診した顔面神経麻痺患者の評価を行い，主観的 評価法との比較，及びENoG，積分筋電図との比較を行った。

【結果】アプリでの評価は既存の主観的評価方法と相関しており，特に㚘頁，鼻翼，口角では強い相関が見られた. また，ENoGでは相関関係が見られなかったものの，積分筋電図でも相関が見られた.

【結論】デバイスは一般に普及しているため，臨床応用に向けての素地は整っており，目的としていた客観的かつ 簡便な評価アプリは開発出来た. 顔面の動きの捉え方は，病態生理に基づきさらなる検証およびアップデートが 必要ではあるが，非耳鼻科医，さらに言えば患者本人でも現状評価を行うことができるようになることが期待さ れる.

キーワード：顔面神経麻痺，iPhone，アプリ

\title{
Development of an iPhone app to evaluate facial nerve palsy
}

Koki Hasebe, Ryusuke Hori, Tsuyoshi Kojima, Yusuke Okanoue, Shintaro Fujimura, Hiroki Kagoshima, Atsushi Taguchi, Kazuhiko Shoji

Department of Otolaryngology, Tenri Hospital 


$$
\text { キースライド }
$$

1

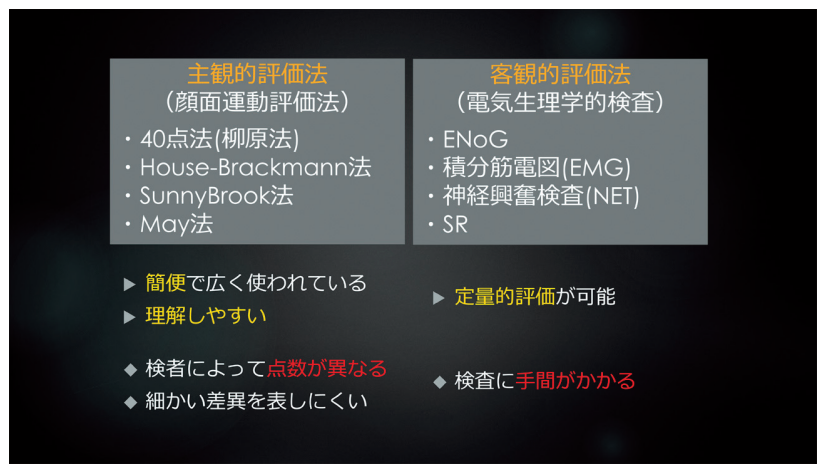

3

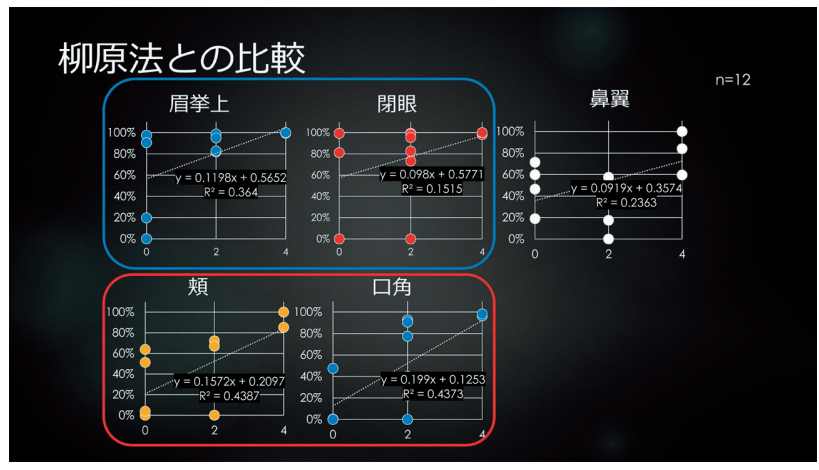

5

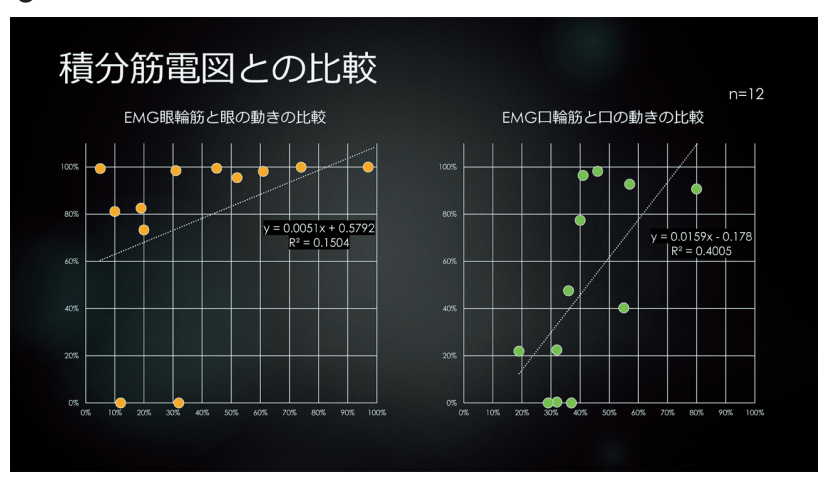

2

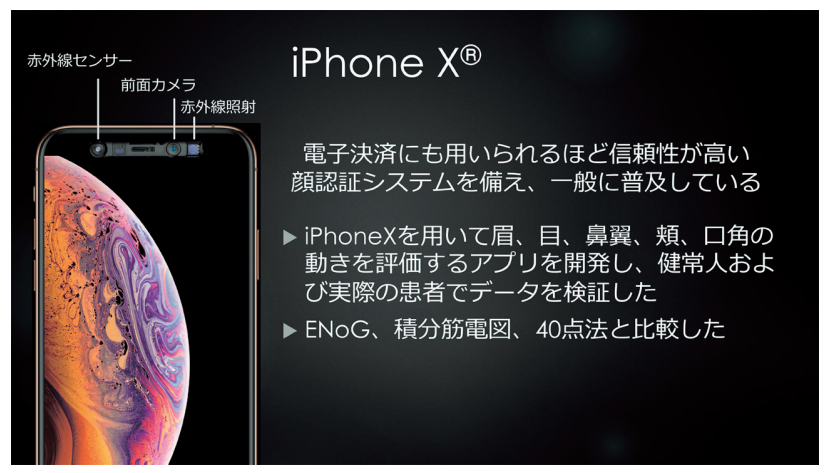

4

ENoGとの比較

ENoG眼输筋と眼の動さの比較

ENoG口輪筋と口角の動きの比較
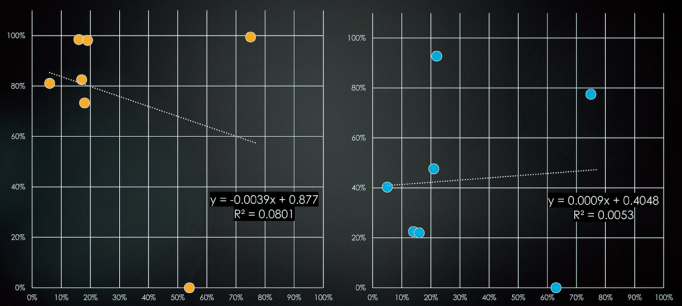

6

考察

$\checkmark$ iPhoneのFacelDを利用し顔面の 動きを3次元的に測定することが可 能

○従来の方法と高い相関を示し、顔 面神経麻瘦の客観的評価方法とし て有用

https://apps.apple.com/us/app /facialpalsyzero/id 1 493697509

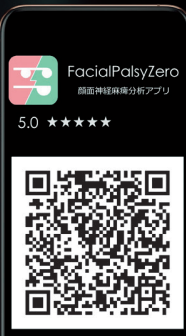

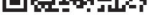

